\title{
Update on the NCEP ATP-III emerging cardiometabolic risk factors
}

\author{
Robert H Eckel ${ }^{*}$ and Marc-Andre Cornier
}

\begin{abstract}
The intent of this review is to update the science of emerging cardiometabolic risk factors that were listed in the National Cholesterol Education Program (NCEP) Adult Treatment Panel-III (ATP-III) report of 2001 (updated in 2004). At the time these guidelines were published, the evidence was felt to be insufficient to recommend these risk factors for routine screening of cardiovascular disease risk. However, the panel felt that prudent use of these biomarkers for patients at intermediate risk of a major cardiovascular event over the subsequent 10 years might help identify patients who needed more aggressive low density lipoprotein (LDL) or non-high density lipoprotein (HDL) cholesterol lowering therapy. While a number of other emerging risk factors have been identified, this review will be limited to assessing the data and recommendations for the use of apolipoprotein B, lipoprotein (a), homocysteine, pro-thrombotic factors, inflammatory factors, impaired glucose metabolism, and measures of subclinical atherosclerotic cardiovascular disease for further cardiovascular disease risk stratification.
\end{abstract}

Keywords: Apolipoprotein B, Lipoprotein (a), C-reactive protein, Homocysteine

\section{Introduction}

It has been long known that certain factors and conditions are associated with increased risk for cardiovascular disease (CVD) and when present warrant more aggressive management. These major risk factors include age, sex, family history, hypertension, diabetes, cholesterol and smoking, with elevated high density lipoprotein (HDL) cholesterol as being protective or a 'negative' risk factor. These major risk factors were the basis for the recommendations set forth by the National Cholesterol Education Program (NCEP) Adult Treatment Panel-III (ATP-III) report of 2001 [1] (updated in 2004) [2]. A number of other cardiometabolic risk factors, so called 'emerging risk factors', have also been identified and reviewed [3,4]. These risk factors include, but are not limited to, obesity, metabolic syndrome, hypertriglyceridemia, apolipoprotein B, lipoprotein (a), homocysteine, pro-thrombotic factors, pro-inflammatory factors as well as measures of subclinical atherosclerotic cardiovascular disease (ASCVD). At the time the ATP-III report was published the evidence was felt to be insufficient to recommend these risk factors

\footnotetext{
* Correspondence: robert.eckel@ucdenver.edu

Division of Endocrinology, Metabolism and Diabetes, University of Colorado School of Medicine, Anschutz Medical Campus, Mail Stop 8106, 12801 E 17th Ave, Aurora, CO 80045, USA
}

for routine screening of CVD. However, the ATP-III panel felt that prudent use of these biomarkers for patients at intermediate risk of a major CVD event over the subsequent 10 years might help identify patients who needed more aggressive low density lipoprotein (LDL) or non-HDL cholesterol lowering therapy.

The more recent 2013 American College of Cardiology/ American Heart Association (ACC/AHA) Guideline on the Assessment of Cardiovascular Risk has also made recommendations on the use of some of these emerging risk factors, including markers of inflammation and subclinical ASCVD [5]. The European (European Guidelines on Cardiovascular Disease Prevention in Clinical Practice) [6] and Canadian (2012 Update of the Canadian Cardiovascular Society Guidelines for the Diagnosis and Treatment of Dyslipidemia for the Prevention of Cardiovascular Disease in the Adult) [7] guidelines have also been recently updated, both reviewing and making recommendations on a number of these emerging cardiometabolic risk factors. These recommendations have been summarized in Table 1 illustrating the lack of consensus regarding these risk factors.

\section{Biomed Central}

(C) 2014 Eckel and Cornier; licensee BioMed Central Ltd. This is an Open Access article distributed under the terms of the Creative Commons Attribution License (http://creativecommons.org/licenses/by/4.0), which permits unrestricted use, distribution, and reproduction in any medium, provided the original work is properly cited. 
Table 1 European, Canadian and ACC/AHA guidelines on the use of emerging risk factors

\begin{tabular}{|c|c|c|c|}
\hline Emerging risk factor & European [6] & Canadian [7] & ACC/AHA [5] \\
\hline Apo B & $\begin{array}{l}\text { No added value; may be a more accurate } \\
\text { assessment of CVD risk versus LDL-C in } \\
\text { patients with hypertriglyceridemia }\end{array}$ & $\begin{array}{l}\geq 120 \mathrm{mg} / \mathrm{dL} \text { as an alternative } \\
\text { marker for intermediate risk } \\
\text { patients with } \mathrm{LDL}-\mathrm{C}<3.5 \mathrm{mmol} / \mathrm{L}\end{array}$ & Screening not recommended \\
\hline Lipoprotein (a) & Screening not recommended & $\begin{array}{l}\text { Consider for intermediate risk } \\
\text { patients. Levels }>30 \mathrm{mg} / \mathrm{dL} \\
\text { considered higher CVD risk }\end{array}$ & Screening not recommended \\
\hline Homocysteine & $\begin{array}{l}\text { May be used in persons at moderate } \\
\text { CVD risk. }\end{array}$ & Screening not recommended & Screening not recommended \\
\hline Pro-thrombotic factors & $\begin{array}{l}\text { Fibrinogen may be used in persons at } \\
\text { moderate CVD risk. }\end{array}$ & Screening not recommended & Screening not recommended \\
\hline Pro-inflammatory factors & $\begin{array}{l}\text { hsCRP may be used in persons at } \\
\text { moderate CVD risk. }\end{array}$ & Screening not recommended & $\begin{array}{l}\text { Consider screening with hsCRP } \\
\text { for intermediate risk patients and } \\
\text { consider statin therapy for } \\
\text { patients with levels } \geq 2 \mathrm{mg} / \mathrm{dL} \text {. }\end{array}$ \\
\hline Impaired fasting glucose & Screening not recommended & $\begin{array}{l}\text { Recommended for all for risk } \\
\text { stratification and diagnosis of } \\
\text { diabetes }\end{array}$ & Screening not recommended \\
\hline Subclinical atherosclerosis & $\begin{array}{l}\text { Consider statin therapy for asymptomatic } \\
\text { patients at moderate risk with carotid } \\
\text { plaque } \geq 0.5 \mathrm{~mm} \text { of IMT or IMT } \geq 1.5 \mathrm{~mm} \text {. } \\
\text { Recommendations based on CCS are } \\
\text { vague but a high CCS is a high CVD risk } \\
\text { and a statin should be prescribed. }\end{array}$ & $\begin{array}{l}\text { For intermediate risk patients } \\
\text { consider statin therapy for } \\
\text { patients with carotid plaque or } \\
\text { CIMT }>75 \text { th \%tile for age and } \\
\text { gender; and for a CCS }>100 \\
\text { Agatston units. }\end{array}$ & $\begin{array}{l}\text { Consider statin therapy for patients } \\
\text { with a calculated } 10 \text { year CVD risk } \\
\text { between } 5.0 \% \text { to } 7.5 \% \text { or even } \\
<5.0 \% \text { with a CCS } \geq 300 \text { Agatston } \\
\text { units or } \geq 75^{\text {th }} \% \text { tile for age, gender } \\
\text { and ethnicity. }\end{array}$ \\
\hline
\end{tabular}

ACC/AHA, American College of Cardiology/American Heart Association; Apo-B, apolipoprotein B; CCS; CIMT, carotid intima-media thickness; CVD, cardiovascular disease; hsCRP, high sensitivity C-reactive protein; IMT, intima media thickness; LDL-C, low density lipoprotein cholesterol.

\section{Review}

\section{Apolipoprotein B}

Apolipoprotein B (apo B) is the major protein on proatherogenic lipoproteins (apo B-containing lipoproteins). There is one molecule of apo B in very low density lipoprotein (VLDL), VLDL remnants, low density lipoprotein (LDL) and lipoprotein (a) particles establishing levels of apo B as a reference to pro-atherogenic particles. Levels of apo B correlate well with levels of non-HDL-C, $r>0.80$ [8-10]. Because levels of apo B represent all proatherogenic particles, the replacement of fasting plasma lipids with apo B to assess CVD risk has been supported by many $[11,12]$. An additional advantage of measuring apo $\mathrm{B}$ as compared to lipids is that fasting may not be necessary because changes in apo B100 after eating are minimally different than those measured in the fed state $[13,14]$. However, although more recent analyses have found that non-HDL-C and apo B perform better than LDL-C in CVD risk prediction, both on- and off-treatment, as well as in subclinical CVD risk prediction [15], the current dogma from the Emerging Risk Factors Collaboration remains that apo B is similar to LDL-C and non-HDL-C in the prediction of CVD [16]. Moreover, when compared to total cholesterol/HDL cholesterol in primary [17] and secondary [18] CVD prevention trials, apo B was similar or weaker than the ratio, respectively, in predicting CVD events.

An important situation in which apo $\mathrm{B}$ may have value is in patients in whom LDL-C levels are low, for example, $<100 \mathrm{mg} / \mathrm{dL}$, and plasma triglycerides (TG) are elevated. Although levels of non-HDL-C may be helpful, apo B may provide additional information about the number of pro-atherogenic particles. It is important to realize that for any given level of non-HDL-C the $95^{\text {th }}$ percentage confidence intervals for apo B puts the apo B level up to two-fold different [19] and this may be especially important in the assessment and treatment of patients with hypertriglyceridemia. Because LDL-C is low, a much greater percentage of apo B is from apo B-containing particles other than LDL such as VLDL or IDL, and with a potential two-fold difference in apo $\mathrm{B}$ at any given level of LDL-C $(<100 \mathrm{mg} / \mathrm{dL})$, the level of apo B could be low at $65 \mathrm{mg} / \mathrm{dL}$ or high at $130 \mathrm{mg} / \mathrm{dL}$; and thus provide markedly different levels of CVD risk. In subjects selected from 2,023 consecutive patients attending the Lipid Clinic at the Laval University Centre, 270 had mild hypertriglyceridemia and normal levels of apo B, 163 moderate hypertriglyceridemia and normal apo B, 458 mild hypertriglyceridemia with elevations in apo B, and 295 moderate hypertriglyceridemia with elevations in apo B [20]. Irrespective of levels of plasma apo B, patients with mild versus moderate hypertriglyceridemia had lower ratios of VLDL apo B/plasma apo B, a discrepancy that may be important to the CVD risk. In fact, in the Quebec Cardiovascular Study the relative risk for CVD based on apo B in patients with hypertriglyceridemia has been well documented [21]. Presently, both the Canadian Guidelines and the American College of Cardiology 
(ACC)/American Diabetes Association (ADA) have established goals for apo B. The Canadian Guidelines have established apo B goals of $<80 \mathrm{mg} / \mathrm{dL}$ and $<100$ $\mathrm{mg} / \mathrm{dL}$ for patients with CVD or at higher risk versus lower CVD risk [22]. The ACC/ADA have set goals of apo $B$ at $<80 \mathrm{mg} / \mathrm{dL}$ for patients with CVD or diabetes and one risk factor and $<90 \mathrm{mg} / \mathrm{dL}$ for patients with two or more risk factors or with diabetes [23].

\section{Lipoprotein (a)}

Lipoprotein (a) is an apo B lipoprotein that includes apolipoprotein (a) covalently bound to apo B. Plasma concentrations of lipoprotein (a) are conferred mostly by genetics that relate primarily to the size of the apo (a) protein. The size of the isoform is dependent on a variable number of kringle IV repeats in the lipoprotein (a) gene [24] and a smaller number of repeats predict a higher concentration of lipoprotein (a) [25]. Lipoprotein (a) concentrations can vary between undetectable to $>200 \mathrm{mg} / \mathrm{dL}$ with a two to three fold higher level seen in populations of African descent. Plasma levels $>30 \mathrm{mg} / \mathrm{dL}$ confer increased atherosclerotic risk [26]. The atherogenicity relates to multiple features of the particle including the inability of the particle to be cleared by the LDL receptor, anti-fibrinolytic properties due to the structural homology to plasminogen and competition with plasminogen for its binding site, and the particle carrying more atherogenic pro-inflammatory oxidized phospholipids [27].

The relationship between lipoprotein (a) and CVD has been well established. By 2000, there were more than 15 population-based prospective studies that reported on higher levels of lipoprotein (a) and CHD risk, with most reporting positive associations. In 2006, a study of 27,736 healthy women, of whom 12,075 indicated active hormone replacement therapy at study initiation and 15,661 did not, demonstrated that women not taking female hormones had a hazard ratio of future CVD events of 1.8 (highest lipoprotein (a) quintile versus lowest quintile, $P<0.0001)$ after multifactorial risk factor adjustment [28]. For a number of years it was believed that levels $>30$ $\mathrm{mg} / \mathrm{dL}$ were predictive of CHD events; however, more recently, a gradient relationship between higher levels of lipoprotein (a) and CVD has been evidenced. In the Reykjavik Study ( $n=18,569$ ), levels of lipoprotein (a) were measured at baseline from 2,047 patients with a non-fatal or fatal myocardial infarction (MI) versus 3,921 control participants. In addition to examining within-person fluctuations, paired samples were assessed at an interval of 12 years in 372 subjects [29]. The odds ratio for CHD, unaltered after adjustment for established risk factors was 1.60 in a comparison of extreme thirds of baseline lipoprotein (a) concentrations. Moreover, odds ratios increased in parallel with increasing levels of lipoprotein (a). In the Copenhagen Heart Study, the association of lipoprotein (a) levels with CHD was also continuous [30]. Risk rates for CHD of 1.16 and 1.13 were found after lipoprotein (a) data were adjusted for age and sex only and for lipids and other CVD risk factors, respectively, when the top and bottom lipoprotein (a) tertiles were compared. In AIM-HIGH (Atherothrombosis Intervention in Metabolic Syndrome with Low HDL/High Triglyceride and Impact on Global Health Outcomes) study, the baseline and on-study lipoprotein (a) levels were predictive of CVD events in the simvastatin plus placebo (baseline HR: 1.24, $P=0.002)$ as well as in the on-extended release niacin group (HR: 1.21, $P=0.017$ ) [31]. In AIM-HIGH there was a gradient CVD risk across quartiles of lipoprotein (a). Finally, in Jupiter, baseline levels of lipoprotein (a) were not only associated with additional CVD risk, among Caucasian participants residual risk in statin-treated patients was a determinant of residual risk (adjusted HR 1.27, 95\% confidence interval (CI) 1.01to $1.59 ; P=0.04$ [32].

Presently, no data exist to confirm that lowering lipoprotein (a) reduces CVD risk; however, lipoprotein (a) can be reduced by niacin, mipomersen, LDL apheresis, cholesteryl ester transfer protein inhibitors, and estrogens [33]. Of interest, estrogens may confer benefit on CVD events in post-menopausal women with the highest quintile of lipoprotein (a) [28]. A major problem with interpretation of any studies using these medications is that variably other lipoproteins are also altered favorably. The anti-sense oligonucleotide from ISIS [34] may be necessary before the independent effect of lipoprotein (a) lowering is realized.

\section{Homocysteine}

Hyperhomocysteinemia can be as a result of deficiencies of vitamin B6, folic acid or vitamin B12 or due to a rare genetic enzyme defect. Hyperhomocysteinemia was first associated with CVD risk as it relates to the rare autosomal recessive disorder, homocystinuria. Individuals with homocystinuria have markedly elevated levels of plasma homocysteine and have a very high risk of CVD if untreated [35]. While the mechanisms are not clearly elucidated, it appears that homocysteinemia is associated with endothelial dysfunction and increased thrombosis [36]. Furthermore, observational studies, both retrospective and prospective, have shown that even moderate elevations in homocysteine, even within the normal range, are also associated with a higher risk of CVD [37,38]. A number of clinical trials have since been published examining the effects of folic acid/B vitamin supplementation on preventing CVD events [39-45]. These studies have been done in individuals of moderate to very high risk of CVD events and, while homocysteine levels are reduced with folic acid/B vitamin supplementation, none of these studies has shown a benefit in clinical CVD outcomes. Clarke and colleagues recently published a meta-analysis of these 
outcome trials [46]. They included eight trials comprising a total of 37,485 individuals and found that lowering homocysteine levels by about $25 \%$ for a mean of five years was not associated with significant beneficial effects on CVD events. Specifically, no benefit was seen in major CVD events (HR 1.01, CI 0.97 to 1.05), major coronary events (HR 1.03, CI 0.97 to 1.10), stroke (HR 0.96, CI 0.87 to 1.06 ), or all-cause mortality (HR 1.00 , CI 0.85 to 1.18 ) [46]. The available evidence, therefore, does not support the routine use of folic acid/B vitamin supplementation to prevent cardiovascular disease or improve overall survival, and as such there are no official recommendations for routine testing for homocysteine.

\section{Pro-thrombotic factors}

Thrombosis is a critical process in the pathophysiology associated with acute CVD events such as acute coronary syndromes [47-49]. An unstable atherosclerotic plaque may be prone to disruption leading to platelet aggregation and acute thrombosis. Platelet activation has also been shown to play an important role in driving atherosclerosis progression as a mediator of endothelial function and inflammatory responses [48]. Furthermore, there is strong evidence supporting the benefits of antiplatelet agents, such as aspirin, in the primary and secondary therapy of CVD [50]. A recent meta-analysis found that aspirin therapy in primary prevention trials was associated with a $12 \%$ reduction in serious CVD events but no effect on stroke or vascular mortality. In secondary prevention, aspirin was associated with a more robust $18 \%$ reduction in serious CVD events [51]. Men appear to receive more benefit from aspirin in primary prevention of CHD events while women appear to receive more benefit in primary prevention of ischemic strokes [51].

It is less clear, however, whether biomarkers associated with thrombosis and platelet aggregation are helpful in clinical practice. Fibrinogen is a major coagulation protein that plays a key role in blood viscosity and platelet aggregation, and in a meta-analysis of prospective observational studies a moderately strong association has been found between fibrinogen levels and the risk of CVD [52,53]. However, because of analytical/assay concerns and uncertainty in treatment strategies, the measurement of fibrinogen in clinical practice is not currently recommended [54]. Circulating tissue plasminogen activator (t-PA) antigen, total plasminogen inhibitor-1 (tPAI-1), D-dimer, and von Willebrand factor have also been found to be associated with increased CVD risk, but more studies are needed to assess their clinical applicability [55-57]. Furthermore, there are no known related therapeutic interventions that are available or proven successful.

\section{Pro-inflammatory factors}

Inflammation has been known to be a critical process in the long-term progression of atherosclerosis for some time $[47,49,58]$. C-reactive protein (CRP) is an acute phase reactant that has been used as a marker of systemic inflammation in rheumatologic disorders. Retrospective and prospective studies have found that high sensitivity CRP (hsCRP) elevations are associated with acute CVD events [59]. Ridker et al. found that men participating in the Physicians' Health Study who had hsCRP levels in the highest quartile had a relative risk of 2.9 for $\mathrm{MI}$ and 1.9 for ischemic stroke compared to those in the lowest quartile [59]. Furthermore, they found that aspirin was associated with significant reductions in the risk of MI in those with the highest hsCRP levels [59]. Ridker et al. also found that hsCRP was a strong predictor of CVD events in women participating in the Women's Health Study and that hsCRP may be a stronger predictor of CVD events than LDL-C levels [60]. Furthermore, recent meta-analyses have found that hsCRP is associated with risk for CVD events and mortality $[61,62]$. There also appears to be a relationship between hsCRP and LDL-C lowering. In the PROVE IT Study, hsCRP lowering with statin therapy was associated with reduced CVD events regardless of the LDL-C lowering [63]. In the JUPITER Study, rosuvastatin significantly decreased CVD events in patients with elevated hsCRP ( $>2 \mathrm{mg} / \mathrm{L})$ and 'normal' LDL-C $(<130 \mathrm{mg} / \mathrm{dL})$ [64], suggesting the importance of hsCRP as a marker of CVD risk and response to statin therapy. There is little evidence, though, that lowering hsCRP levels prevents CVD events [61]. In light of these findings, the new 2013 ACC/AHA Guideline on the Assessment of Cardiovascular Risk recommends that, based on expert opinion, measurement hsCRP may be considered as a marker of risk to inform decision making on treatment options [5]. There is evidence, though, to suggest that an anti-inflammatory agent such as methotrexate is associated with reduced CVD events in patients treated for rheumatoid arthritis [65]. As such, there are currently trials designed to examine whether anti-inflammatory agents reduce CVD risk by reducing systemic inflammation, such as the Cardiovascular Inflammation Reduction Trial sponsored by the National Heart, Lung, and Blood Institute and Brigham and Women's Hospital investigating whether low dose methotrexate reduces CVD outcomes in high risk individuals, which may provide evidence for using inflammatory markers as a treatment target.

\section{Impaired glucose metabolism}

Hyperglycemia and diabetes mellitus are clearly associated with increased CVD risk [66-68]. There is evidence, though, that mild hyperglycemia below the cutoffs for diabetes is also associated with increased CVD risk [68]. Mild hyperglycemia or 'pre-diabetes' can manifest as either impaired fasting glucose (IFG), impaired glucose tolerance (IGT), and/or elevated hemoglobin A1c (HbA1c). These impairments in glucose metabolism are associated with insulin 
resistance and other cardiometabolic risk factors, such as high blood pressure, dyslipidemia, pro-inflammatory state and pro-thrombotic state, all resulting in increased risk for CVD [69]. It is more controversial whether hyperglycemia, especially at mild, pre-diabetes levels, is a direct cause of CVD. IFG using cutoffs of $110 \mathrm{mg} / \mathrm{dl}(6.0 \mathrm{mmol} / \mathrm{l})$ [70] and $100 \mathrm{mg} / \mathrm{dl}(5.6 \mathrm{mmol} / \mathrm{l})$ [71] has been shown to be independently associated with increased CVD risk [72-74]. In a recent meta-analysis, Ford et al. found that IFG was associated with an $18 \%$ to $20 \%$ increased risk in CVD [74]. Interestingly, as has been shown in patients with 'frank' diabetes [66], Levitzky et al. found that women with IFG had a close to 1.7 to 2.2 fold increase in CHD while no effect was seen in men [73]. Others, though, have not found a sex-based difference in risk [74]. IGT has also been shown to be associated with an increased risk of CVD [74-76]. It is less clear, however, whether treating pre-diabetes improves CVD outcomes. A number of diabetes prevention studies, including the Diabetes Prevention Program, have been performed in individuals with IGT but none have been powered to examine CVD outcomes [77]. Thus, the modest risk of CVD seen in those with pre-diabetes may be a result of the associated comorbidities as opposed to a direct effect of the mild hyperglycemia.

\section{Subclinical ASCVD}

Subclinical atherosclerosis is common and responsible for first CVD events including major coronary artery occlusion including sudden death in $40 \%$ to $60 \%$ of CHD patients in the United States [78]. This section will address only non-invasive techniques to assess this disease burden. Ankle-brachial index (ABI) is a cheap, easily employed method to asses for peripheral arterial disease (PAD) and as a predictor of CVD events. The ABI is the ankle systolic blood pressure divided by the brachial artery systolic blood pressure obtained while the patient is supine with a value of $\leq 0.9$ considered abnormal. Despite its simplicity, the United States Preventive Services Task Force has determined that 'the current evidence is insufficient to assess the balance of benefits and harms of screening for PAD and CVD risk assessment with the ABI in adults' [79]. B-mode ultrasonography is most often utilized to assess the thickness of the arterial intimal and the medial layers (CIMT) in the common carotid artery. However, the 2013 ACC/AHA Guideline on the Assessment of Cardiovascular Risk Work Group report judged that the evidence provided by Den Ruijter et al. [80] in combination with the concerns about measurement quality failed to provide sufficient rationale to recommend measuring common carotid IMT in routine clinical practice for CVD risk assessment for a first atherosclerotic cardiovascular disease (ASCVD) event [5]. Moreover, the systematic review of van den Oord et al. failed to demonstrate added value of carotid IMT to traditional risk models in predicting CVD events [81]. Important issues related to carotid IMT as an assessment of ASCVD risk include measurement error and standardization. The Den Ruijter et al. report was a meta-analysis of 14 population-based cohorts with a median follow-up of 11 years in 45,828 individuals with 4,007 MIs or strokes.

Electron-beam computed tomography (CT) measures coronary artery calcification, a process related to the lipid and apoptotic characteristics of the plaque. In 1,726, $57.7+/$ - 13.3-year-old, asymptomatic individuals, an Agatston score $>75$ th percentile was associated with a higher annualized event rate for myocardial infarction $(3.6 \%$ versus $1.6 \%, P<0.05)$ and for cardiac death $(2.2 \%$ versus $0.9 \%)$ compared with patients with scores $<75$ th percentile [82]. Moreover, no cardiac events were observed in patients with coronary calcium scores of zero. In the Multi-Ethnic Study of Atherosclerosis (MESA), 6,814 subjects were examined over a mean follow-up period of 7.6 years to determine the area under the receiver operator characteristic (ROC) curve (AUC) and net reclassification improvement of coronary calcium in comparison to a series of additional CVD risk factors when added to the Framingham Risk Score [83]. In MESA, the coronary artery calcium was superior to other predictors of $\mathrm{CHD} / \mathrm{CVD}$, such as hsCRP, family history and ankle-brachial index, in reclassifying risk and discriminating the extent of $\mathrm{CHD}$ in intermediate-risk subjects. This study is particularly important because the improvement in ROC characteristics improved prediction above and beyond current multivariate prediction models.

The 2013 ACC/AHA Guideline on the Assessment of Cardiovascular Risk Work Group notes used the systematic review by Peters et al. [84]. to provide evidence that assessing coronary artery calcification is likely to be the most useful of the current approaches to improving risk assessment among individuals found to be at intermediate risk after formal risk assessment [5]. Furthermore, the Work Group noted that the outcomes in the studies reviewed by Peters et al. [84]. and by Greenland et al. [85] were CHD outcomes, not hard ASCVD events that included stroke; thus, uncertainty remains regarding the contribution of assessing coronary artery calcium to estimating 10-year risk of first hard ASCVD events after formal risk assessment using the new Pooled Cohort Equations. Furthermore, issues of cost and radiation exposure related to measuring coronary calcium were discussed resulting in some uncertainty regarding potential risks of more widespread screening; thus, a Class IIb recommendation was given for individuals for whom a risk-based treatment decision is uncertain after formal risk estimation. Recent MESA data have provided additional information that not only the volumetric score but the density of the plaque need to be considered in 
the prediction of CVD events to follow [86]. In this analysis at any level of plaque volume, coronary artery calcium density was inversely and significantly associated with CHD and CVD risk. This result suggests that plaque remodeling by reduction in apo B-containing lipoproteins and inflammation may serve to consolidate lesions and render them more stable.

By obtaining ECG-gated images, contrast-enhanced multi-slice or multi-detector CT, also known as MDCT, provides a more sensitive method than electron beam CT to detail coronary anatomy. Moreover, diagnostic performance of coronary $\mathrm{CT}$ angiography has been substantially improved with the technological developments in multi-slice CT scanners which started with 4-slice and now has advanced to 320-slice capability [87]. The exact place of MDCT remains unclear but the elimination of unnecessary high dose radiation exposure is an important consideration [88]. Perhaps the best place for MDCT is as an alternative to invasive coronary angiography in asymptomatic patients who have a positive stress test [88].

High-resolution magnetic resonance imaging (MRI) with contrast may be the most promising technique for studying athero-thrombotic disease in humans [89]. Most importantly, MRI allows for the characterization of plaque composition including the lipid core, fibrosis, calcification, intra-plaque hemorrhage and importantly thrombi, and not only their presence but age, also. In asymptomatic subjects with subclinical markers of CVD and in those with no coronary calcium, coronary artery MRI has been used to detect increased vessel wall thickness [90]. Although there are limitations to its use including image resolution and imaging time, coronary MRI opens new strategies for the screening of higher risk patients for early detection and treatment as well as monitoring of lesions after therapeutic intervention.

\section{Conclusions}

The purpose of this review was to update the science of emerging cardiometabolic risk factors that were originally discussed in the NCEP/ATPIII report of 2001 (updated in 2004). While there are more published data regarding the evidence for using these risk factors there continues to be significant debate and lack of consensus in their use as illustrated in Table 1 which summarizes more current recommendations (European, Canadian and American). Thus, the use of these biomarkers for patients at intermediate risk of a major cardiovascular event remains prudent in assisting in the identification of patients who need more aggressive LDL-C or non-HDL-C lowering therapy.

\section{Abbreviations}

ABI: ankle-brachial index; ACC: American College of Cardiology;

ADA: American Diabetes Aassociation; AHA: American Heart Association; apo B: apolipoprotein B; ASCVD: atherosclerotic cardiovascular disease; ATP: adult treatment panel; AUC: area under the curve; CHD: coronary heart disease; CRP: C reactive protein; CT: computed tomography; CVD: cardiovascular disease; HbA1c: hemoglobin A1c; HDL: high density lipoprotein; HR: hazard ratio; hsCRP: high sensitivity CRP; IFG: impaired fasting glucose; IGT: impaired glucose tolerance; LDL: low density lipoprotein; MDCT: multidetector CT; MESA: Multi-ethnic Study of Atherosclerosis; MI: myocardial infarction; MRI: magnetic resonance imaging; NCEP: National Cholesterol Education Program; PAD: peripheral arterial disease; ROC: receiver operator characteristic; TG: triglycerides; t-PA: tissue plasminogen activator; tPAl-1: total plasminogen inhibitor-1; VLDL: very low density lipoprotein.

\section{Competing interests}

The authors declare that they have no competing interests.

\section{Authors' contributions}

RHE and MC designed the review, conducted a PubMed review of the relevant literature for each emerging risk factor discussed, and drafted the manuscript. Both authors developed conclusions and recommendations based on their expert opinion and the areas reviewed. Both authors read and approved the final manuscript.

\section{Authors' information}

RHE is Professor of Medicine in the Divisions of Endocrinology, Metabolism and Diabetes and Cardiology and Professor of Physiology and Biophysics at the University of Colorado. RHE is the Director of the Lipid Clinic at the University of Colorado Hospital and Past-President of the American Heart Association. MC is an Associate Professor of Medicine in the Division of Endocrinology, Metabolism and Diabetes. MC is the Director of the University of Colorado Hospital LDL Apheresis Program.

Received: 20 March 2014 Accepted: 20 May 2014

Published: 26 Aug 2014

\section{References}

1. Expert Panel on Detection, Evaluation, and Treatment of High Blood Cholesterol in Adults: Executive summary of the third report of the national cholesterol education program (NCEP) expert panel on detection, evaluation, and treatment of high blood cholesterol in adults (Adult Treatment Panel III). JAMA 2001, 285:2486-2497.

2. Grundy SM, Cleeman Jl, Merz CN, Brewer HB Jr, Clark LT, Hunninghake DB, Pasternak RC, Smith SC Jr, Stone NJ, National Heart, Lung, and Blood Institute, American College of Cardiology Foundation, American Heart Association: Implications of recent clinical trials for the National Cholesterol Education Program Adult Treatment Panel III guidelines. Circulation 2004, 110:227-239.

3. Lloyd-Jones DM: Cardiovascular risk prediction: basic concepts, current status, and future directions. Circulation 2010, 121:1768-1777.

4. Tzoulaki I, Liberopoulos G, loannidis JP: Assessment of claims of improved prediction beyond the Framingham risk score. JAMA 2009, 302:2345-2352.

5. Goff DC, Lloyd-Jones DM, Bennett G, Coady S, D'Agostino RB Sr, Gibbons R, Greenland P, Lackland DT, Levy D, O'Donnell CJ, Robinson J, Schwartz JS, Shero ST, Smith SC Jr, Sorlie P, Stone NJ, Wilson PW: ACC/AHA guideline on the assessment of cardiovascular risk: a report of the American college of cardiology/American heart association task force on practice guidelines. Circulation, In press.

6. Perk J, De Backer G, Gohlke H, Graham I, Reiner Z, Verschuren WM, Albus C, Benlian P, Boysen G, Cifkova R, Deaton C, Ebrahim S, Fisher M, Germanò G, Hobbs R, Hoes A, Karadeniz S, Mezzani A, Prescott E, Ryden L, Scherer M, Syvanne M, Scholte Op Reimer WJ, Vrints C, Wood D, Zamorano JL, Zannad F, Comitato per Linee Guida Pratiche (CPG) dell'ESC: European guidelines on cardiovascular disease prevention in clinical practice (version 2012): the fifth joint task force of the European Society of Cardiology and other societies on cardiovascular disease prevention in clinical practice (constituted by representatives of nine societies and by invited experts). Atherosclerosis 2012, 223:1-68.

7. Anderson TJ, Gregoire J, Hegele RA, Couture P, Mancini GB, McPherson R, Francis GA, Poirier P, Lau DC, Grover S, Genest J Jr, Carpentier AC, Dufour R, Gupta M, Ward R, Leiter LA, Lonn E, Ng DS, Pearson GJ, Yates GM, Stone JA, Ur E: 2012 update of the Canadian Cardiovascular Society guidelines for the diagnosis and treatment of dyslipidemia for the prevention of cardiovascular disease in the adult. Can J Cardiol 2013, 29:151-167.

8. Chien KL, Hsu HC, Su TC, Chen MF, Lee YT, Hu FB: Apolipoprotein B and non-high density lipoprotein cholesterol and the risk of coronary heart disease in Chinese. J Lipid Res 2007, 48:2499-2505. 
9. Grundy SM, Vega GL, Tomassini JE, Tershakovec AM: Comparisons of apolipoprotein B levels estimated by immunoassay, nuclear magnetic resonance, vertical auto profile, and non-high-density lipoprotein cholesterol in subjects with hypertriglyceridemia (SAFARI Trial). Am J Cardiol 2011, 108:40-46.

10. Ridker PM, Rifai N, Cook NR, Bradwin G, Buring JE: Non-HDL cholesterol, apolipoproteins $\mathrm{A}-\mathrm{I}$ and B100, standard lipid measures, lipid ratios, and CRP as risk factors for cardiovascular disease in women. JAMA 2005, 294:326-333.

11. Vaverkova H, Farnier M, Averna M, Missault L, Viigimaa M, Dong Q, Shah A Johnson-Levonas AO, Brudi P: Switching from statin monotherapy to ezetimibe/simvastatin or rosuvastatin modifies the relationships between apolipoprotein B, LDL cholesterol, and non-HDL cholesterol in patients at high risk of coronary disease. Clin Biochem 2011, 44:627-634.

12. Sniderman AD, Islam S, Yusuf S, McQueen MJ: Discordance analysis of apolipoprotein $B$ and non-high density lipoprotein cholesterol as markers of cardiovascular risk in the INTERHEART study. Atherosclerosis 2012, 225:444-449

13. Langsted A, Nordestgaard BG: Nonfasting lipids, lipoproteins, and apolipoproteins in individuals with and without diabetes: 58434 individuals from the Copenhagen general population study. Clin Chem 2011, 57:482-489.

14. Mora S, Rifai N, Buring JE, Ridker PM: Fasting compared with nonfasting lipids and apolipoproteins for predicting incident cardiovascular events. Circulation 2008, 118:993-1001

15. Ramjee V, Sperling LS, Jacobson TA: Non-high-density lipoprotein cholesterol versus apolipoprotein B in cardiovascular risk stratification: do the math. J Am Coll Cardiol 2011, 58:457-463.

16. Emerging Risk Factors Collaboration, Di Angelantonio E, Sarwar N, Perry P, Kaptoge S, Ray KK, Thompson A, Wood AM, Lewington S, Sattar N, Packard CJ, Collins R, Thompson SG, Danesh J: Major lipids, apolipoproteins, and risk of vascular disease. JAMA 2009, 302:1993-2000.

17. Mora S, Glynn RJ, Boekholdt SM, Nordestgaard BG, Kastelein JJ, Ridker PM: On-treatment non-high-density lipoprotein cholesterol, apolipoprotein B triglycerides, and lipid ratios in relation to residual vascular risk after treatment with potent statin therapy: JUPITER (justification for the use of statins in prevention: an intervention trial evaluating rosuvastatin). J Am Coll Cardiol 2012, 59:1521-1528.

18. Pedersen TR, Olsson AG, Faergeman O, Kjekshus J, Wedel H, Berg K, Wilhelmsen L, Haghfelt T, Thorgeirsson G, Pyörälä K, Miettinen T, Christophersen B, Tobert JA, Musliner TA, Cook TJ: Lipoprotein changes and reduction in the incidence of major coronary heart disease events in the Scandinavian Simvastatin Survival Study (4S). Circulation 1998, 97:1453-1460.

19. Sniderman AD, St-Pierre AC, Cantin B, Dagenais GR, Despres JP, Lamarche B: Concordance/discordance between plasma apolipoprotein B levels and the cholesterol indexes of atherosclerotic risk. Am J Cardiol 2003, 91:1173-1177.

20. Sniderman AD, Tremblay A, De Graaf J, Couture P: Phenotypes of hypertriglyceridemia caused by excess very-low-density lipoprotein. J Clin Lipidol 2012, 6:427-433.

21. Lamarche B, Despres JP, Moorjani S, Cantin B, Dagenais GR, Lupien PJ: Prevalence of dyslipidemic phenotypes in ischemic heart disease (prospective results from the Quebec Cardiovascular Study). Am J Cardiol 1995, 75:1189-1195.

22. Contois JH, McConnell JP, Sethi AA, Csako G, Devaraj S, Hoefner DM Warnick GR, AACC Lipoproteins and Vascular Diseases Division Working Group on Best Practices: Apolipoprotein B and cardiovascular disease risk: position statement from the AACC lipoproteins and vascular diseases division working group on best practices. Clin Chem 2009, 55:407-419.

23. Brunzell JD, Davidson M, Furberg CD, Goldberg RB, Howard BV, Stein JH, Witztum JL: Lipoprotein management in patients with cardiometabolic risk: consensus conference report from the American diabetes association and the American college of cardiology foundation. J Am Coll Cardiol 2008, 51:1512-1524

24. McLean JW, Tomlinson JE, Kuang WJ, Eaton DL, Chen EY, Fless GM, Scanu AM, Lawn RM: cDNA sequence of human apolipoprotein(a) is homologous to plasminogen. Nature 1987, 330:132-137.

25. Sandholzer C, Hallman DM, Saha N, Sigurdsson G, Lackner C, Császár A Boerwinkle E, Utermann G: Effects of the apolipoprotein(a) size polymorphism on the lipoprotein(a) concentration in 7 ethnic groups. Hum Genet 1991, 86:607-614
26. Nordestgaard BG, Chapman MJ, Ray K, Borén J, Andreotti F, Watts GF, Ginsberg H, Amarenco P, Catapano A, Descamps OS, Fisher E, Kovanen PT, Kuivenhoven JA, Lesnik P, Masana L, Reiner Z, Taskinen MR, Tokgözoglu L, Tybjærg-Hansen A, European Atherosclerosis Society Consensus Panel: Lipoprotein(a) as a cardiovascular risk factor: current status. Eur Heart J 2010, 31:2844-2853.

27. Tsimikas S, Witztum JL: The role of oxidized phospholipids in mediating lipoprotein(a) atherogenicity. Curr Opin Lipidol 2008, 19:369-377.

28. Suk Danik J, Rifai N, Buring JE, Ridker PM: Lipoprotein(a), hormone replacement therapy, and risk of future cardiovascular events. J Am Coll Cardiol 2008, 52:124-131.

29. Myers RH, Vonsattel JP, Paskevich PA, Kiely DK, Stevens TJ, Cupples LA, Richardson EP Jr, Bird ED: Decreased neuronal and increased oligodendroglial densities in Huntington's disease caudate nucleus. J Neuropathol Exp Neurol 1991, 50:729-742.

30. Emerging Risk Factors Collaboration, Erqou S, Kaptoge S, Perry PL, D Angelantonio E, Thompson A, White IR, Marcovina SM, Collins R, Thompson SG, Danesh J: Lipoprotein(a) concentration and the risk of coronary heart disease, stroke, and nonvascular mortality. JAMA 2009, 302:412-423.

31. Albers JJ, Slee A, O'Brien KD, Robinson JG, Kashyap ML, Kwiterovich PO Jr, Xu P, Marcovina SM: Relationship of apolipoproteins A-1 and B, and lipoprotein(a) to cardiovascular outcomes: the AIM-HIGH trial (Atherothrombosis Intervention in Metabolic Syndrome with Low HDL/High Triglyceride and Impact on Global Health Outcomes). J Am Coll Cardiol 2013, 62:1575-1579.

32. Khera AV, Everett BM, Caulfield MP, Hantash FM, Wohlgemuth J, Ridker PM, Mora S: Lipoprotein(a) concentrations, rosuvastatin therapy, and residual vascular risk: an analysis from the JUPITER Trial (Justification for the Use of Statins in Prevention: an Intervention Trial Evaluating Rosuvastatin). Circulation 2014, 129:635-642.

33. Kolski B, Tsimikas S: Emerging therapeutic agents to lower lipoprotein (a) levels. Curr Opin Lipidol 2012, 23:560-568.

34. Isis Pharmaceuticals Reports Positive Phase 1 Data Demonstrating ISIS-APO(a) Rx Produces Significant Reductions in Lp(a) Levels. http://ir.isispharm.com/phoenix.zhtml?c=222170\&p=irol-newsArticle\&id=1877550.

35. Mudd SH, Skovby F, Levy HL, Pettigrew KD, Wilcken B, Pyeritz RE, Andria G, Boers GH, Bromberg IL, Cerone R, Fowler B, Gröbe H, Schmidt H, Schweitzer $L$ : The natural history of homocystinuria due to cystathionine beta-synthase deficiency. Am J Hum Gen 1985, 37:1-31.

36. Wilcken DE, Wilcken B: B vitamins and homocysteine in cardiovascular disease and aging. Ann N Y Acad Sci 1998, 854:361-370.

37. Danesh J, Lewington S: Plasma homocysteine and coronary heart disease: systematic review of published epidemiological studies. J Cardiovasc Risk 1998, 5:229-232.

38. Homocysteine Studies Collaboration: Homocysteine and risk of ischemic heart disease and stroke: a meta-analysis. JAMA 2002, 288:2015-2022.

39. Toole JF, Malinow MR, Chambless LE, Spence JD, Pettigrew LC, Howard VJ, Sides $\mathrm{EG}$, Wang $\mathrm{CH}$, Stampfer M: Lowering homocysteine in patients with ischemic stroke to prevent recurrent stroke, myocardial infarction, and death: the Vitamin Intervention for Stroke Prevention (VISP) randomized controlled trial. JAMA 2004, 291:565-575.

40. Bonaa KH, Njolstad I, Ueland PM, Schirmer H, Tverdal A, Steigen T, Wang H, Nordrehaug JE, Arnesen E, Rasmussen K, NORVIT Trial Investigators: Homocysteine lowering and cardiovascular events after acute myocardial infarction. N Engl J Med 2006, 354:1578-1588.

41. Lonn E, Yusuf S, Arnold MJ, Sheridan P, Pogue J, Micks M, McQueen MJ, Probstfield J, Fodor G, Held C, Genest J Jr, Heart Outcomes Prevention Evaluation (HOPE) 2 Investigators: Homocysteine lowering with folic acid and B vitamins in vascular disease. N Engl J Med 2006, 354:1567-1577.

42. Jamison RL, Hartigan P, Kaufman JS, Goldfarb DS, Warren SR, Guarino PD, Gaziano JM, Veterans Affairs Site Investigators: Effect of homocysteine lowering on mortality and vascular disease in advanced chronic kidney disease and end-stage renal disease: a randomized controlled trial. JAMA 2007, 298:1163-1170.

43. Albert CM, Cook NR, Gaziano JM, Zaharris E, MacFadyen J, Danielson E, Buring JE, Manson JE: Effect of folic acid and B vitamins on risk of cardiovascular events and total mortality among women at high risk for cardiovascular disease: a randomized trial. JAMA 2008, 299:2027-2036.

44. Ebbing M, Bleie O, Ueland PM, Nordrehaug JE, Nilsen DW, Vollset SE, Refsum H, Pedersen EK, Nygård O: Mortality and cardiovascular events in 
patients treated with homocysteine-lowering B vitamins after coronary angiography: a randomized controlled trial. JAMA 2008, 300:795-804.

45. Study of the Effectiveness of Additional Reductions in Cholesterol and Homocysteine (SEARCH) Collaborative Group, Armitage JM, Bowman L, Clarke RJ, Wallendszus K, Bulbulia R, Rahimi K, Haynes R, Parish S, Sleight P, Peto R, Collins R: Effects of homocysteine-lowering with folic acid plus vitamin B12 vs placebo on mortality and major morbidity in myocardial infarction survivors: a randomized trial. JAMA 2010, 303:2486-2494.

46. Clarke R, Halsey J, Lewington S, Lonn E, Armitage J, Manson JE, Bønaa KH, Spence JD, Nygård O, Jamison R, Gaziano JM, Guarino P, Bennett D, Mir F, Peto R, Collins R, B-Vitamin Treatment Trialists' Collaboration: Effects of lowering homocysteine levels with B vitamins on cardiovascular disease, cancer, and cause-specific mortality: meta-analysis of 8 randomized trials involving 37485 individuals. Arch Intern Med 2010, 170:1622-1631.

47. Fuster V, Badimon L, Badimon JJ, Chesebro JH: The pathogenesis of coronary artery disease and the acute coronary syndromes (1). N Engl J Med 1992, 326:242-250.

48. Badimon L, Padró T, Vilahur G: Atherosclerosis, platelets and thrombosis in acute ischaemic heart disease. Eur Heart J Acute Cardiovasc Care 2012, 1:60-74.

49. Hansson GK: Inflammation, atherosclerosis, and coronary artery disease. N Engl J Med 2005, 352:1685-1695.

50. Buch MH, Prendergast BD, Storey RF: Antiplatelet therapy and vascular disease: an update. Ther Adv Cardiovasc Dis 2010, 4:249-275.

51. Antithrombotic Trialists (ATT) Collaboration, Baigent C, Blackwell L, Collins R, Emberson J, Godwin J, Peto R, Buring J, Hennekens C, Kearney P, Meade T, Patrono C, Roncaglioni MC, Zanchetti A: Aspirin in the primary and secondary prevention of vascular disease: collaborative meta-analysis of individual participant data from randomised trials. Lancet 2009, 373:1849-1860.

52. Fibrinogen Studies Collaboration, Danesh J, Lewington S, Thompson SG, Lowe GD, Collins R, Kostis JB, Wilson AC, Folsom AR, Wu K, Benderly M, Goldbourt U, Willeit J, Kiechl S, Yarnell JW, Sweetnam PM, Elwood PC, Cushman M, Psaty BM, Tracy RP, Tybjaerg-Hansen A, Haverkate F, de Maat MP, Fowkes FG, Lee AJ, Smith FB, Salomaa V, Harald K, Rasi R, Vahtera E, et al: Plasma fibrinogen level and the risk of major cardiovascular diseases and nonvascular mortality: an individual participant meta-analysis. JAMA 2005, 294:1799-1809.

53. Emerging Risk Factors Collaboration, Kaptoge S, Di Angelantonio E, Pennells L, Wood AM, White IR, Gao P, Walker M, Thompson A, Sarwar N, Caslake M, Butterworth AS, Amouyel P, Assmann G, Bakker SJ, Barr EL, Barrett-Connor E, Benjamin EJ, Björkelund C, Brenner H, Brunner E, Clarke R, Cooper JA, Cremer P, Cushman M, Dagenais GR, D'Agostino RB Sr, Dankner R, Davey-Smith $G$, Deeg $D$, et al: C-reactive protein, fibrinogen, and cardiovascular disease prediction. N. Engl. J. Med 2012, 367:1310-1320.

54. NACB LMPG Committee Members, Myers GL, Christenson RH, Cushman M, Ballantyne CM, Cooper GR, Pfeiffer CM, Grundy SM, Labarthe DR, Levy D, Rifai N, Wilson PW: National Academy of Clinical Biochemistry Laboratory Medicine Practice guidelines: emerging biomarkers for primary prevention of cardiovascular disease. Clin Chem 2009, 55:378-384.

55. Lowe GDO, Danesh J, Lewington S, Walker M, Lennon L, Thomson A, Rumley A, Whincup PH: Tissue plasminogen activator antigen and coronary heart disease: Prospective study and meta-analysis. Eur Heart $J$ 2004, 25:252-259.

56. Whincup PH, Danesh J, Walker M, Lennon L, Thomson A, Appleby P, Rumley A, Lowe GD: von Willebrand factor and coronary heart disease: prospective study and meta-analysis. Eur Heart J 2002, 23:1764-1770.

57. Danesh J, Whincup P, Walker M, Lennon L, Thomson A, Appleby P, Rumley A, Lowe GD: Fibrin D-dimer and coronary heart disease: prospective study and meta-analysis. Circulation 2001, 103:2323-2327.

58. Munro JM, Cotran RS: The pathogenesis of atherosclerosis: atherogenesis and inflammation. Laboratory investigation. J Tech Methods Pathol 1988, 58:249-261

59. Ridker PM, Cushman M, Stampfer MJ, Tracy RP, Hennekens $\mathrm{CH}$ : Inflammation, aspirin, and the risk of cardiovascular disease in apparently healthy men. N Engl J Med 1997, 336:973-979.

60. Ridker PM, Rifai N, Rose L, Buring JE, Cook NR: Comparison of C-reactive protein and low-density lipoprotein cholesterol levels in the prediction of first cardiovascular events. N Engl J Med 2002, 347:1557-1565.

61. Buckley DI, Fu R, Freeman M, Rogers K, Helfand M: C-reactive protein as a risk factor for coronary heart disease: a systematic review and meta-analyses for the U.S. Preventive Services Task Force. Ann Intern Med 2009, 151:483-495.

62. Emerging Risk Factors Collaboration, Kaptoge S, Di Angelantonio E, Lowe G, Pepys MB, Thompson SG, Collins R, Danesh J: C-reactive protein concentration and risk of coronary heart disease, stroke, and mortality: an individual participant meta-analysis. Lancet 2010, 375:132-140.

63. Ridker PM, Cannon CP, Morrow D, Rifai N, Rose LM, McCabe CH, Pfeffer MA, Braunwald E, Pravastatin or Atorvastatin Evaluation and Infection Therapy-Thrombolysis in Myocardial Infarction 22 (PROVE IT-TIMI 22) Investigators: C-reactive protein levels and outcomes after statin therapy. N Engl J Med 2005, 352:20-28.

64. Ridker PM, Danielson E, Fonseca FA, Genest J, Gotto AM Jr, Kastelein JJ, Koenig W, Libby P, Lorenzatti AJ, MacFadyen JG, Nordestgaard BG, Shepherd J, Willerson JT, Glynn RJ, JUPITER Study Group: Rosuvastatin to prevent vascular events in men and women with elevated C-reactive protein. N. Engl. J. Med 2008, 359:2195-2207.

65. Westlake SL, Colebatch AN, Baird J, Kiely P, Quinn M, Choy E, Ostor AJ, Edwards CJ: The effect of methotrexate on cardiovascular disease in patients with rheumatoid arthritis: a systematic literature review. Rheumatology (Oxford) 2010, 49:295-307.

66. Lee WL, Cheung AM, Cape D, Zinman B: Impact of diabetes on coronary artery disease in women and men: a meta-analysis of prospective studies. Diabetes Care 2000, 23:962-968.

67. von Gunten E, Braun J, Bopp M, Keller U, Faeh D: J-shaped association between plasma glucose concentration and cardiovascular disease mortality over a follow-up of 32years. Prev Med 2013, 57:623-628.

68. Park C, Guallar E, Linton JA, Lee DC, Jang Y, Son DK, Han EJ, Baek SJ, Yun YD, Jee SH, Samet JM: Fasting glucose level and the risk of incident atherosclerotic cardiovascular diseases. Diabetes Care 2013, 36:1988-1993.

69. Grundy SM: Pre-diabetes, metabolic syndrome, and cardiovascular risk. J Am Coll Cardiol 2012, 59:635-643.

70. Report of the Expert Committee on the Diagnosis and Classification of Diabetes Mellitus. Diabetes Care 1997, 20:1183-1197.

71. Genuth S, Alberti KG, Bennett P, Buse J, Defronzo R, Kahn R, Kitzmiller J, Knowler WC, Lebovitz H, Lernmark A, Nathan D, Palmer J, Rizza R, Saudek C, Shaw J, Steffes M, Stern M, Tuomilehto J, Zimmet P, Expert Committee on the Diagnosis and Classification of Diabetes Mellitus: Follow-up report on the diagnosis of diabetes mellitus. Diabetes Care 2003, 26:3160-3167.

72. Coutinho M, Gerstein HC, Wang Y, Yusuf S: The relationship between glucose and incident cardiovascular events. A metaregression analysis of published data from 20 studies of 95,783 individuals followed for 12.4 years. Diabetes Care 1999, 22:233-240.

73. Levitzky YS, Pencina MJ, D'Agostino RB, Meigs JB, Murabito JM, Vasan RS, Fox CS: Impact of impaired fasting glucose on cardiovascular disease: the Framingham Heart Study. J Am Coll Cardiol 2008, 51:264-270.

74. Ford ES, Zhao G, Li C: Pre-diabetes and the risk for cardiovascular disease: a systematic review of the evidence. J Am Coll Cardiol 2010, 55:1310-1317.

75. Decode Study Group tEDEG, the European Diabetes Epidemiology Group: Glucose tolerance and cardiovascular mortality: comparison of fasting and 2-hour diagnostic criteria. Arch Intern Med 2001, 161:397-405.

76. Levitan EB, Song Y, Ford ES, Liu S: Is nondiabetic hyperglycemia a risk factor for cardiovascular disease? A meta-analysis of prospective studies. Arch Intern Med 2004, 164:2147-2155.

77. Ratner R, Goldberg R, Haffner S, Marcovina S, Orchard T, Fowler S, Temprosa M, Diabetes Prevention Program Research Group: Impact of intensive lifestyle and metformin therapy on cardiovascular disease risk factors in the diabetes prevention program. Diabetes Care 2005, 28:888-894.

78. Pfleeger T, Blakeley-Smith M, King G, Henry Lee E, Plocher M, Olszyk D: The effects of glyphosate and aminopyralid on a multi-species plant field trial. Ecotoxicology 2012, 21:1771-1787.

79. Moyer VA, U.S. Preventive Services Task Force: Screening for peripheral artery disease and cardiovascular disease risk assessment with the ankle-brachial index in adults: U.S. Preventive Services Task Force recommendation statement. Ann Intern Med 2013, 159:342-348.

80. Den Ruijter HM, Peters SA, Anderson TJ, Britton AR, Dekker JM, Eijkemans MJ, Engström G, Evans GW, de Graaf J, Grobbee DE, Hedblad B, Hofman A Holewijn S, Ikeda A, Kavousi M, Kitagawa K, Kitamura A, Koffijberg H, Lonn EM, Lorenz MW, Mathiesen EB, Nijpels G, Okazaki S, O'Leary DH, Polak JF, Price JF, Robertson C, Rembold CM, Rosvall M, Rundek T, et al: Common carotid intima-media thickness measurements in cardiovascular risk prediction: a meta-analysis. Jama 2012, 308:796-803. 
81. van den Oord SC, Sijbrands EJ, ten Kate GL, van Klaveren D, van Domburg RT, van der Steen AF, Schinkel AF: Carotid intima-media thickness for cardiovascular risk assessment: systematic review and meta-analysis. Atherosclerosis 2013, 228:1-11.

82. Becker A, Leber A, Becker C, Knez A: Predictive value of coronary calcifications for future cardiac events in asymptomatic individuals. Am Heart J 2008, 155:154-160.

83. Yeboah J, McClelland RL, Polonsky TS, Burke GL, Sibley CT, O'Leary D, Carr JJ, Goff DC, Greenland P, Herrington DM: Comparison of novel risk markers for improvement in cardiovascular risk assessment in intermediate-risk individuals. JAMA 2012, 308:788-795.

84. Peters SA, den Ruijter HM, Bots ML, Moons KG: Improvements in risk stratification for the occurrence of cardiovascular disease by imaging subclinical atherosclerosis: a systematic review. Heart 2012, 98:177-184.

85. Greenland P, Alpert JS, Beller GA, Benjamin EJ, Budoff MJ, Fayad ZA, Foster E, Hlatky MA, Hodgson JM, Kushner FG, Lauer MS, Shaw LJ, Smith SC Jr, Taylor AJ, Weintraub WS, Wenger NK, Jacobs AK, American College of Cardiology Foundation/American Heart Association Task Force on Practice Guidelines: 2010 ACCF/AHA guideline for assessment of cardiovascular risk in asymptomatic adults: a report of the American College of Cardiology Foundation/American Heart Association Task Force on Practice Guidelines. Circulation 2010, 122:e584-e636.

86. Criqui MH, Denenberg JO, Ix JH, McClelland RL, Wassel CL, Rifkin DE, Carr JJ, Budoff MJ, Allison MA: Calcium density of coronary artery plaque and risk of incident cardiovascular events. JAMA 2014, 311:271-278.

87. Pelliccia F, Pasceri V, Evangelista A, Pergolini A, Barillà F, Viceconte N, Tanzilli G, Schiariti M, Greco C, Gaudio C: Diagnostic accuracy of 320-row computed tomography as compared with invasive coronary angiography in unselected, consecutive patients with suspected coronary artery disease. Int J Cardiovas Imag 2013, 29:443-452.

88. Sun Z, Aziz YF, Ng KH: Coronary CT angiography: how should physicians use it wisely and when do physicians request it appropriately? Eur J Radiol 2012, 81:e684-e687.

89. Corti R, Fuster V: Imaging of atherosclerosis: magnetic resonance imaging. Eur Heart J 2011, 32:1709-19b.

90. Macedo R, Chen S, Lai S, Shea S, Malayeri AA, Szklo M, Lima JA, Bluemke DA: MRI detects increased coronary wall thickness in asymptomatic individuals: the multi-ethnic study of atherosclerosis (MESA). J Magn Reson Imaging 2008, 28:1108-1115.

10.1186/1741-7015-12-115

Cite this article as: Eckel and Cornier: Update on the NCEP ATP-III emerging cardiometabolic risk factors. BMC Medicine 2014, 12:115

\section{Submit your next manuscript to BioMed Central and take full advantage of:}

- Convenient online submission

- Thorough peer review

- No space constraints or color figure charges

- Immediate publication on acceptance

- Inclusion in PubMed, CAS, Scopus and Google Scholar

- Research which is freely available for redistribution 